\title{
Australian Journal of Crop Science \\ Effect of gamma irradiation on the 2-acetyl-1-pyrroline content during growth of Thai black glutinous rice (Upland rice)
}

\author{
Sompong Sansenya ${ }^{1 *}$, Yanling Hua ${ }^{2}$, Saowapa Chumanee ${ }^{3}$ and Chanakan Winyakul ${ }^{3}$ \\ ${ }^{1}$ Department of Chemistry, Faculty of Science and Technology, Rajamangala University of Technology \\ Thanyaburi, Pathum Thani 12110, Thailand \\ ${ }^{2}$ The Center for Scientific and Technological Equipment, Suranaree University of Technology, Nakhon \\ Ratchasima 30000, Thailand \\ ${ }^{3}$ Division of Chemistry, Faculty of Science and Technology, Phetchabun Rajabhat University, Mueang, \\ Phetchabun 67000, Thailand
}

\section{*Corresponding author: sompong_s@rmutt.ac.th}

\begin{abstract}
2-acetyl-1-pyrroline (2AP) is the characteristic compound for the fragrant rice. 2AP accumulation in rice can be affected by environmental factors such as salinity, drought stress and solar intensity. In this study, the accumulation of $2 \mathrm{AP}$ content during growth of Thai black glutinous rice (Upland rice) was investigated. Furthermore, we also investigated the effect of gamma irradiation on plant growth, grain weight and 2AP content of irradiated rice, compared to non-irradiated rice. The results revealed that $2 \mathrm{AP}$ was accumulated in shoots and roots of rice. The highest $2 \mathrm{AP}$ content in roots was found in seedling stage I and about 2-fold higher when compared with $2 \mathrm{AP}$ in shoots at the same stage. After seedling stage I, the $2 \mathrm{AP}$ content of roots decreased and was lower than $2 \mathrm{AP}$ content of shoots. The results indicated that 2AP content may be migrated from roots in seedling stage I into other part of rice after this stage. When rice grains were subjected to ${ }^{137} \mathrm{Cs}$ gamma irradiation, shoot length, 2AP content and grain weight of irradiated rice was investigated and compared with non-irradiated rice. Shoot length of irradiated rice was higher than non-irradiated rice at low gamma dose, while the high gamma dose inhibited the shoot length of irradiated rice. The trend of 2AP content in shoots and roots of irradiated rice in some gamma doses were higher than non-irradiated rice. Moreover, the 2AP content of shorter irradiated rice shoots seems to be higher than of longer-irradiated rice shoots. The gamma ray caused the reduction of grain weight in irradiated rice, while the $2 \mathrm{AP}$ content in grain of irradiated rice was higher than non-irradiated rice. This report suggests that the gamma irradiation technique cloud induce the growth of rice and improve the $2 \mathrm{AP}$ content in rice.
\end{abstract}

Keywords: 2-acetyl-1-pyrroline; Aroma volatile compounds; Betain aldehyde dehydrogenase; Gamma irradiation technique; Gas Chromatography-Mass Spectrometry.

Abbreviations: 2AP_2-acetyl-1-pyrroline; Badh2_dominant betain aldehyde dehydrogenase gene; badh2_recessive betain aldehyde dehydrogenase gene; BADH2_betain aldehyde dehydrogenase; GABald_ $\gamma$-aminobutyraldehyde; TMP_trimethyl pyridine; MRM_Multi reaction monitoring; GC-MS_Gas Chromatography-Mass Spectrometry.

\section{Introduction}

More than 100 aroma volatile compounds have been reported in rice. Among these, 2-acetyl-1-pyrroline (2AP) is the main characteristic of the fragrance rice (Yajima et al., 1978; 1979; Buttery et al., 1982; Widjaja et al., 1996; Maraval et al., 2008). 2AP has been reported in many plants including sorghum (Prasada and Murty, 1979; Yundaeng et al. 2013), pandan leaves (Buttery et al., 1983), wild mango seeds (Tairu et al., 2000), green teas (Japanese kamairi-cha and Chinese longing tea) (Kumazawa and Masuda, 2002), fresh bread flowers (Vallaris glabra Ktze.) (Wongpornchai et al., 2003), vegetable soybean (Glycine max L.) (Wu et al., 2009), peanuts (Kaneko et al., 2013), hazelnut (Corylus avellana L.) (Kiefl et al., 2013) and pumpkin seed oil (Cucurbita pepo subsp. pepo var. Styriaca) (Poehlmann and Schieberle, 2013).

In rice, $2 \mathrm{AP}$ has been synthesized via L-proline metabolism and associated with recessive betain aldehyde dehydrogenase gene (badh2), which is a recessive gene located on chromosome 8 . The badh 2 gene encoding inactive betaine aldehyde dehydrogenase (BADH2) activates the synthesis of $2 \mathrm{AP}$, while dominant betain aldehyde dehydrogenase gene (Badh2) encoding the active BADH2 inhibits the synthesis of 2AP (Bradbury et al., 2005; 2008; Chen et al., 2008). In the biochemical pathway of 2AP synthesis, when there is a presence of non-functional $\mathrm{BADH} 2$, the substrate $\gamma$ aminobutyraldehyde (GABald) is converted to form $\Delta^{1}$ pyrroline and finally acetylated to form 2AP (Bradbury et al., 2008 and Chen et al., 2008). Furthermore, the nitrogen in pyrroline ring is formed from nitrogen of proline, but the carbon in acetyl group of 2AP is not from carbon of proline (Yoshihashi et al., 2002). In some cases, in fragrance rice varieties, the nitrogen atom of $2 \mathrm{AP}$ is derived from glutamic acid (Huang et al., 2008). The 2AP content has been accumulated in all parts of fragrance rice except for roots and its level is relatively higher in aerial part than other parts (Yoshihashi et al., 1999). The accumulation of 2AP in rice is corresponded with transcription level of Badh2 gene. Previous researches reported that Badh2 is expressed in all 
rice tissue including roots but in less abundance. There is more transcript abundance of $B a d h 2$ in young tissues than in mature tissues. Moreover, the less transcription level of Badh2 has been reported in aroma rice than non-aroma rice (Chen et al., 2008; Niu et al., 2008; Hinge et al., 2016).

The synthesis and accumulation of 2AP content in rice can be affected from many environmental factors such as drought, salinity and shading treatments. For example, Gay et al. (2010) and Poonlaphdecha et al. (2012) reported that 2AP formation increased due to increase in salt concentration. Moreover, Yoshihashi et al. (2004) reported that drought stress has an effect on increasing 2AP concentration in grains during period of grains formation. Recently, one of environmental factors, level of solar radiation from shading treatment, has been studied, where the results showed that 2AP content in grains of all shading treatments were significantly increased, compared to rice without shading treatment (Mo et al., 2015).

Gamma ray is a type of ionizing radiation, a technique that is used for mutation induction of many organisms (Kovács and Keresztes, 2002), and major crops such as maize, wheat, and barley (Warchalewski et al., 2000; Marcu et al., 2013; Kara et al., 2015). In rice, gamma irradiation technique has been mostly used for improvement of grain quality, plant resistance to diseases, cold stress, salt stress tolerant, effect on seed germination and variation of shoot length and root length (Harding et al., 2012). Gamma irradiation can change some chemical compounds in brown rice (Japonica rice) such as increasing the pasting values of rice grains but decreasing free fatty acid of rice grains, while low scores for odor was observed in the gamma irradiated brown rice (Chen et al., 2015). Moreover, an increase of tocopherol content is observed in the irradiated rice compared to non-irradiated rice (Hwang et al., 2014).

In this research, the accumulation of $2 \mathrm{AP}$ content in shoots and roots of Thai black glutinous rice (Upland rice) were investigated during growth of rice. Moreover, the accumulation of $2 \mathrm{AP}$ content and rice growth rate of irradiated rice were observed and compared with nonirradiated rice.

\section{Results}

\section{Effect of gamma irradiation on shoot length of rice}

Table 1, showed that shoot length of irradiated rice significantly $(P<0.05)$ increased in all of the gamma doses except for $20 \mathrm{~Gy}$, compared with non-irradiated rice. The shoot length of irradiated rice increased from 40 Gy to 150 Gy, and then decreased continuously from 200 Gy to $250 \mathrm{~Gy}$. The highest shoot length was observed when the rice was subjected to gamma dose at $150 \mathrm{~Gy}$. The growth rate trend of non-irradiated rice was increased from seedling stage I to flowering stage with a measured shoot length between $4.43 \pm$ $0.83 \mathrm{~cm}$ to $40.96 \pm 1.06 \mathrm{~cm}$, and a similar trend was observed in irradiated rice at all gamma doses. At 20 gamma dose, increasing trend was observed in shoot length at seedling stage I to middle tillering stage $(3.99 \pm 0.42 \mathrm{~cm}$ to $20.20 \pm$ $0.69 \mathrm{~cm})$ and continued to panicle initiation stage $(20.81 \pm$ $0.60 \mathrm{~cm}$ ). However, the growth of $20 \mathrm{~Gy}$-irradiated rice was rapidly decreased after panicle initiation stage and plant died between panicle initiation to flowering stage. Furthermore, at $40 \mathrm{~Gy}$, the shoot length of irradiated rice was slightly decreased at flowering stage $(47.91 \pm 0.51 \mathrm{~cm})$, when compared with panicle initiation stage (52 days) (49.67 \pm $0.96 \mathrm{~cm})$.

\section{$2 A P$ content in shoots and roots during growth stage of non-irradiated rice}

2AP content of shoots and roots of non-irradiated rice were determined during growth of rice (Table 2 and Table 3 ). The highest $2 \mathrm{AP}$ content of shoots and roots were obtained from shoots of seedling stage II $\left(55.53 \pm 0.53 \mu \mathrm{g} . \mathrm{g}^{-1}\right)$ and roots of seedling stage $\mathrm{I}\left(30.86 \pm 1.30 \mu \mathrm{g} \cdot \mathrm{g}^{-1}\right)$, respectively. The lowest $2 \mathrm{AP}$ content was obtained from shoots at seedling stage I $\left(14.23 \pm 0.30 \mu \mathrm{g} \cdot \mathrm{g}^{-1}\right)$ and roots of seedling stage II $\left(1.69 \pm 0.80 \mu \mathrm{g} \cdot \mathrm{g}^{-1}\right)$, respectively. The trend of $2 \mathrm{AP}$ content was variable during rice growth. In shoot an increase of 3.9fold 2AP was observed in seedling stage II, compared to seedling stage I. After this highest value, $2 \mathrm{AP}$ content decreased at middle tillering stage to panicle initiation stage, then increased again at flowering stage until the harvest stage. In the root part, $2 \mathrm{AP}$ content was also variable but with a different pattern when compared with the shoot part. 2AP content of seedling stage II showed 18.3-fold lower than seedling stage I, which increased again at middle tillering stage, and then slightly decreasing at panicle initiation stage (Table 3).

\section{Effect of gamma irradiation on $2 A P$ content in shoots and roots rice}

2AP content was determined from shoots and roots of irradiated rice during growth stage (same as non-irradiated rice) (Table 2 and Table 3). The concentration of $2 \mathrm{AP}$ in shoots were $14.23 \pm 0.30 \mu \mathrm{g} . \mathrm{g}^{-1}$ to $55.53 \pm 0.53 \mu \mathrm{g} . \mathrm{g}^{-1}$ for non-irradiated rice ( 0 Gy) and $11.97 \pm 0.47 \mu \mathrm{g} . \mathrm{g}^{-1}$ to $68.02 \pm$ $0.93 \mu \mathrm{g} . \mathrm{g}^{-1}$ for irradiated rice (20 Gy to $250 \mathrm{~Gy}$ ), respectively. At the $20 \mathrm{~Gy}$, in the shoots, the $2 \mathrm{AP}$ content increased from seedling stage I to panicle initiation stage $\left(21.01 \pm 0.97 \mu \mathrm{g} . \mathrm{g}^{-1}\right.$ to $\left.68.02 \pm 0.93 \mu \mathrm{g} . \mathrm{g}^{-1}\right)$, while a variable trend of $2 \mathrm{AP}$ content was observed in other gamma doses ( $40 \mathrm{~Gy}$ to $250 \mathrm{~Gy})$ and also in non-irradiated rice $(0 \mathrm{~Gy})$ (Table 2). Moreover, 2AP content of shoots at panicle initiation stage ( 52 days) of irradiated rice ( $20 \mathrm{~Gy}$ to $250 \mathrm{~Gy}$ ) had $15.13 \pm 0.53 \mu \mathrm{g} . \mathrm{g}^{-1}$ to $68.02 \pm 0.93 \mu \mathrm{g} . \mathrm{g}^{-1}$, and higher than $14.27 \pm 0.36 \mu \mathrm{g} \cdot \mathrm{g}^{-1}$ in non-irradiated rice. Similar result was observed at harvested stage (101 days) of irradiated rice shoots, which had $33.92 \pm 1.07 \mu \mathrm{g}^{-\mathrm{g}^{-1}}$ to $54.16 \pm 0.54 \mu \mathrm{g} . \mathrm{g}$ ${ }^{1}$ and higher than $32.71 \pm 0.34 \mu \mathrm{g} \cdot \mathrm{g}^{-1}$ in non-irradiated rice shoots.

2AP content of non-irradiated rice roots had $1.69 \pm 0.80$ $\mu \mathrm{g} . \mathrm{g}^{-1}$ to $30.86 \pm 1.30 \mu \mathrm{g} . \mathrm{g}^{-1}$, while $1.01 \pm 0.26 \mu \mathrm{g} \cdot \mathrm{g}^{-1}$ to $19.26 \pm 1.11 \mu \mathrm{g} . \mathrm{g}^{-1}$ were obtained from irradiated rice roots (20 Gy to $250 \mathrm{~Gy}$ ). The highest $2 \mathrm{AP}$ content of nonirradiated rice roots were observed at seedling stage I (7 days) $\left(30.86 \pm 1.30 \mu \mathrm{g} . \mathrm{g}^{-1}\right)$, while the highest $2 \mathrm{AP}$ content of irradiated rice roots $\left(19.26 \pm 1.11 \mu \mathrm{g} \cdot \mathrm{g}^{-1}\right)$ was identified from $20 \mathrm{~Gy}$. Moreover, the 2AP content obtained from seedling stage II to panicle initiation stage of rice roots were lower than seedling stage I of all gamma doses and also in nonirradiated rice (Table 3). The gamma irradiation affected $2 \mathrm{AP}$ content of irradiated rice roots with 1.6-fold to 4.0-fold lower than those of non-irradiated rice roots at seedling stage I. On the other hand, at seedling stage II, the 2AP content of irradiated rice roots had 1.3-fold to 6.5-fold higher than those of non-irradiated rice roots. 
Table 1. Effect of gamma irradiation on shoot length of variant stage of growth rice.

\begin{tabular}{lccccc}
\hline \multirow{2}{*}{ Gamma doses (Gy) } & \multicolumn{5}{c}{ Shoot length $(\mathrm{cm})$} \\
\cline { 2 - 6 } & 7 days & 14 days & 37 days & 52 days & 74 days \\
\hline 0 & $4.43 \pm 0.83^{\mathrm{ef}}$ & $8.91 \pm 0.49^{\mathrm{e}}$ & $30.37 \pm 0.46^{\mathrm{e}}$ & $38.03 \pm 0.97^{\mathrm{d}}$ & $40.96 \pm 1.06^{\mathrm{c}}$ \\
20 & $3.99 \pm 0.42^{\mathrm{e}}$ & $8.72 \pm 0.43^{\mathrm{e}}$ & $20.20 \pm 0.69^{\mathrm{h}}$ & $20.81 \pm 0.60^{\mathrm{h}}$ & $\mathrm{NM}^{\mathrm{h}}$ \\
40 & $6.46 \pm 0.28^{\mathrm{d}}$ & $9.61 \pm 0.06^{\mathrm{d}}$ & $45.26 \pm 0.95^{\mathrm{b}}$ & $49.67 \pm 0.96^{\mathrm{b}}$ & $47.91 \pm 0.51^{\mathrm{b}}$ \\
60 & $7.36 \pm 0.39^{\mathrm{c}}$ & $9.64 \pm 0.24^{\mathrm{d}}$ & $21.37 \pm 0.49^{\mathrm{g}}$ & $28.80 \pm 0.95^{\mathrm{g}}$ & $29.89 \pm 0.86^{\mathrm{f}}$ \\
80 & $8.79 \pm 0.19^{\mathrm{b}}$ & $11.93 \pm 0.15^{\mathrm{c}}$ & $33.72 \pm 0.56^{\mathrm{c}}$ & $35.03 \pm 0.86^{\mathrm{e}}$ & $36.48 \pm 0.76^{\mathrm{e}}$ \\
100 & $8.94 \pm 0.20^{\mathrm{ab}}$ & $12.89 \pm 0.24^{\mathrm{b}}$ & $31.04 \pm 0.71^{\mathrm{ed}}$ & $36.30 \pm 0.89^{\mathrm{e}}$ & $38.39 \pm 0.87^{\mathrm{d}}$ \\
150 & $9.52 \pm 0.20^{\mathrm{a}}$ & $14.13 \pm 0.40^{\mathrm{a}}$ & $47.69 \pm 0.59^{\mathrm{a}}$ & $58.94 \pm 0.89^{\mathrm{a}}$ & $59.28 \pm 0.84^{\mathrm{a}}$ \\
200 & $9.11 \pm 0.08^{\mathrm{ab}}$ & $12.61 \pm 0.13^{\mathrm{b}}$ & $31.82 \pm 0.43^{\mathrm{d}}$ & $47.70 \pm 0.79^{\mathrm{c}}$ & $47.22 \pm 0.93^{\mathrm{b}}$ \\
250 & $4.83 \pm 0.23^{\mathrm{e}}$ & $9.94 \pm 0.15^{\mathrm{d}}$ & $25.14 \pm 0.79^{\mathrm{f}}$ & $33.08 \pm 0.38^{\mathrm{f}}$ & $37.33 \pm 1.02^{\mathrm{de}}$ \\
\hline
\end{tabular}

Mean, in a column, \pm denotes standard deviation of means $(n=6)$, followed by the same letters under the same column indicates no significant difference (Duncan test, $\mathrm{P}$ $>0.05$ ). NM, means no measurement, indicates the plants were died before the date of measurement.

Table 2. 2AP content of non-irradiated rice shoots ( $0 \mathrm{~Gy})$ and irradiated rice shoots (20 Gy to $250 \mathrm{~Gy}$ ) of variant stage of growth rice.

\begin{tabular}{|c|c|c|c|c|c|c|}
\hline Gamma doses (Gy) & \multicolumn{6}{|c|}{ 2-acetyl-1-pyrroline content $\left(\mu \mathrm{g} \cdot \mathrm{g}^{-1}\right)$ of shoot } \\
\hline 20 & $21.01 \pm 0.97^{\mathrm{c}}$ & $47.38 \pm 0.65^{\mathrm{c}}$ & $51.73 \pm 1.08^{\mathrm{a}}$ & $68.02 \pm 0.93^{\mathrm{a}}$ & NM & NM \\
\hline 60 & $14.80 \pm 0.41^{\mathrm{ef}}$ & $15.77 \pm 1.04^{\mathrm{g}}$ & $11.97 \pm 0.47 \mathrm{f}^{\mathrm{g}}$ & $17.37 \pm 0.56^{\mathrm{f}}$ & $14.95 \pm 0.93^{f}$ & $35.98 \pm 1.04^{\mathrm{d}}$ \\
\hline 80 & $6.15 \pm 0.56^{\mathrm{g}}$ & $21.98 \pm 1.00^{\mathrm{f}}$ & $13.67 \pm 0.96^{\mathrm{f}}$ & $35.71 \pm 0.39^{\mathrm{c}}$ & $36.21 \pm 0.87^{\mathrm{a}}$ & $33.92 \pm 1.07^{\mathrm{ef}}$ \\
\hline 100 & $31.92 \pm 0.59^{\mathrm{b}}$ & $20.95 \pm 1.05^{\mathrm{f}}$ & $14.93 \pm 0.80^{\mathrm{f}}$ & $15.13 \pm 0.53^{\mathrm{g}}$ & $17.22 \pm 0.89^{\mathrm{e}}$ & $34.61 \pm 0.46^{\mathrm{de}}$ \\
\hline 250 & $17.37 \pm 0.71^{\mathrm{d}}$ & $62.26 \pm 1.61^{\mathrm{a}}$ & $34.05 \pm 1.07^{\mathrm{b}}$ & $19.10 \pm 0.85^{\mathrm{e}}$ & $29.09 \pm 1.05^{\mathrm{b}}$ & $45.78 \pm 1.06^{\mathrm{b}}$ \\
\hline
\end{tabular}

Mean, in a column, \pm denotes standard deviation of means $(\mathrm{n}=3)$, followed by the same letters under the same column indicates no significant difference (Duncan test, $\mathrm{P}$

$>0.05$ ). NM, means no measurement, indicates the plants were died before the date of measurement.

Table 3. $2 \mathrm{AP}$ content of non-irradiated rice roots $(0 \mathrm{~Gy})$ and irradiated rice roots (20 Gy to $250 \mathrm{~Gy})$ of variant stage of growth rice.

\begin{tabular}{lcccc}
\hline \multirow{2}{*}{ Gamma doses $(G y)$} & \multicolumn{4}{c}{$\begin{array}{c}\text { 2-acetyl-1-pyrroline content } \\
\left(\mu \mathrm{g} . \mathrm{g}^{-1}\right)\end{array}$} \\
\cline { 2 - 5 } & 7 Days & 14 Days & 37 Days & 52 Days \\
\cline { 2 - 5 } & $30.86 \pm 1.30^{\mathrm{a}}$ & $1.69 \pm 0.80^{\mathrm{d}}$ & $7.19 \pm 0.37^{\mathrm{c}}$ & $5.28 \pm 0.80^{\mathrm{d}}$ \\
20 & $19.26 \pm 1.11^{\mathrm{b}}$ & $2.53 \pm 0.59^{\mathrm{cd}}$ & $4.65 \pm 0.62^{\mathrm{e}}$ & $\mathrm{NM}$ \\
40 & $7.72 \pm 0.50^{\mathrm{e}}$ & $4.95 \pm 0.35^{\mathrm{b}}$ & $11.00 \pm 0.24^{\mathrm{a}}$ & $\mathrm{NM}$ \\
60 & $11.06 \pm 1.40^{\mathrm{d}}$ & $3.04 \pm 0.31^{\mathrm{c}}$ & $3.61 \pm 0.43^{\mathrm{e}}$ & $7.02 \pm 0.14^{\mathrm{a}}$ \\
80 & $7.61 \pm 0.78^{\mathrm{e}}$ & $2.62 \pm 0.38^{\mathrm{cd}}$ & $8.87 \pm 1.11^{\mathrm{b}}$ & $6.64 \pm 0.55^{\mathrm{ab}}$ \\
100 & $11.32 \pm 0.41^{\mathrm{d}}$ & $11.04 \pm 0.88^{\mathrm{a}}$ & $6.60 \pm 0.86^{\mathrm{cd}}$ & $1.01 \pm 0.26^{\mathrm{e}}$ \\
150 & $17.36 \pm 1.52^{\mathrm{c}}$ & $4.15 \pm 0.40^{\mathrm{b}}$ & $5.91 \pm 0.26^{\mathrm{d}}$ & $5.73 \pm 0.38^{\mathrm{cd}}$ \\
200 & $15.62 \pm 0.90^{\mathrm{c}}$ & $2.28 \pm 0.26^{\mathrm{cd}}$ & $6.81 \pm 0.60^{\mathrm{cd}}$ & $7.07 \pm 0.18^{\mathrm{a}}$ \\
250 & $12.89 \pm 0.94^{\mathrm{d}}$ & $3.05 \pm 0.27^{\mathrm{c}}$ & $8.25 \pm 0.54^{\mathrm{b}}$ & $6.08 \pm 0.19^{\mathrm{bc}}$ \\
\hline
\end{tabular}

Mean, in a column, \pm denotes standard deviation of means $(\mathrm{n}=3)$, followed by the same letters under the same column indicates no significant difference (Duncan test, $\mathrm{P}$ $>0.05$ ) NM, means no measurement, the irradiated rice at $20 \mathrm{~Gy}$ indicates the plants were died before the date of measurement and the irradiated rice at $40 \mathrm{~Gy}$ the amount of samples were lower than measurement.

Table 4. Effect of gamma irradiation on yield and $2 \mathrm{AP}$ content of rice grains.

\begin{tabular}{lcc}
\hline Gamma doses $(\mathrm{Gy})$ & $\begin{array}{c}100 \text {-grain weight } \\
(\mathrm{g})\end{array}$ & $\begin{array}{c}\text { 2-acetyl-1-pyrroline } \\
\left(\mu \mathrm{g} \cdot \mathrm{g}^{-1}\right)\end{array}$ \\
\hline 0 & $7.47 \pm 0.82^{\mathrm{a}}$ & $8.76 \pm 0.44^{\mathrm{e}}$ \\
20 & $\mathrm{NM}$ & $\mathrm{NM}$ \\
40 & $5.41 \pm 0.37^{\mathrm{bc}}$ & $13.28 \pm 0.27^{\mathrm{c}}$ \\
60 & $4.65 \pm 0.67^{\mathrm{c}}$ & $18.17 \pm 0.44^{\mathrm{b}}$ \\
80 & $4.49 \pm 0.46^{\mathrm{c}}$ & $25.08 \pm 0.92^{\mathrm{a}}$ \\
100 & $5.75 \pm 0.39^{\mathrm{b}}$ & $7.47 \pm 0.42^{\mathrm{f}}$ \\
150 & $7.94 \pm 0.78^{\mathrm{a}}$ & $11.62 \pm 0.60^{\mathrm{d}}$ \\
200 & $\mathrm{NM}$ & $\mathrm{NM}$ \\
250 & $1.35 \pm 0.13^{\mathrm{d}}$ & $18.57 \pm 0.43^{\mathrm{b}}$ \\
\hline
\end{tabular}

Mean, in a column, \pm denotes standard deviation of means $(\mathrm{n}=3)$, followed by the same letters under the same column indicates no significant difference (Duncan test, $\mathrm{P}$ $>0.05$ ). NM, means no measurement, indicates the irradiated rice at $20 \mathrm{~Gy}$ was died before the date of measurement, and the irradiated rice at $200 \mathrm{~Gy}$ the mature seed cannot be observed. 


\section{Effect of gamma irradiation on $2 A P$ content and yield of} rice grains

In grains, an increase of $2 \mathrm{AP}$ content was observed in irradiated rice grains with $11.62 \pm 0.60 \mu \mathrm{g} . \mathrm{g}^{-1}$ to $25.08 \pm 0.92$ $\mu \mathrm{g} . \mathrm{g}^{-1}$, compared to non-irradiated rice grains $(8.76 \pm 0.44$ $\left.\mu \mathrm{g} . \mathrm{g}^{-1}\right)$ except for $100 \mathrm{~Gy}\left(7.47 \pm 0.42 \mu \mathrm{g} . \mathrm{g}^{-1}\right)$. The highest $2 \mathrm{AP}$ content was found at $80 \mathrm{~Gy}$, which was 3 -fold higher than non-irradiated rice grains (Table 4 ).

The gamma irradiation caused the reduction of the 100grain weight of irradiated rice ( $40 \mathrm{~Gy}$ to $250 \mathrm{~Gy}$ ), with a range of $1.35 \pm 0.13 \mathrm{~g}$ to $5.75 \pm 0.39 \mathrm{~g}$, except for $150 \mathrm{~Gy}$ $(7.94 \pm 0.78 \mathrm{~g})$ when compared to non-irradiated rice $(7.47 \pm$ $0.82 \mathrm{~g}$ ) (Table 4).

\section{Discussion}

Our results showed that, shoot length of irradiated rice (40 Gy to 250 Gy) at seedling stage I and stage II was significantly higher than non-irradiated rice ( 0 Gy). Moreover, the shoot length of irradiated rice treated with low gamma dose was higher than irradiated rice treated with high gamma dose. The shoot length of irradiated rice treated with high gamma dose showed a decrease when compared with non-irradiated rice. However, at $200 \mathrm{~Gy}$, the differentiation of rice flower of irradiated rice plant to mature seed cannot be observed. Our results are in accordance with the finding of previous reports which state that the increasing of gamma dose induced the decreasing of growth rate of rice and other plants, such as grapevine, red pepper (Capsicum annuum L.), corn and maize (Zea mays), (Charbaji and Nabulsi, 1999; Kim et al., 2004; Kim et al., 2005; Emrani et al., 2013; Marcu et al., 2013; Hwang et al., 2014). Moreover, previous reports and our results suggest that a lower gamma dose may induce the growth rate of rice, while higher gamma dose seem to inhibit the growth rate of rice. The increasing of rice growth under treatment with low gamma dose can be explained by several hypotheses. Akshatha et al. (2016) reported that the significant increase of total chlorophyll content was observed at low gamma dose of seedling plant, and the increasing of germination percentage also observed in irradiated germinated plant when compared to non-irradiated germinated plant. The increasing of photosynthetic pigment induced through low gamma dose, and plant growth was also stimulated by low gamma dose (Kim et al., 2005). The increasing of proline content has been reported when seedling wheat (Triticum Aestivum L.) treated with low gamma doses and increasing of shoot weight is due to low dose of gamma irradiation. A low gamma dose seems to induce plant growth and also induce some biochemical compound. On the other hand, the decreasing of plant growth is affected by high gamma dose has been reported. Previous results showed that the inhibit of cell division and the decrease in biochemical compound such as soluble protein content, proline content and chlorophyll content are due to high gamma dose and might be hypothesized for decrease of plant growth by high gamma irradiation (Preuss et al., 2003; Kiong et al., 2008; Marcu et al., 2013).

$2 \mathrm{AP}$ acts as the characteristic aroma compound of fragrance rice such as Khao Dawk Mali 105, the famous fragrance rice from Thailand (Yoshihashi et al., 2002). The $2 \mathrm{AP}$ content has been reported both in fragrance rice and also in non-fragrance rice but shown in trace amounts (Widjaja et al., 1996; Bounphanousay et al., 2008). In our study, 2AP content was measured from shoots of Thai black glutinous rice during the growth stage. The highest $2 \mathrm{AP}$ content was found at seedling stage II, and the lowest $2 \mathrm{AP}$ content found at seedling stage I. These results were contrasting to the Aychade fragrant rice variety, where the highest $2 \mathrm{AP}$ content of rice was obtained from panicle initiation stage, and the lowest 2AP content was obtained from middle tillering stage (Poonlaphdecha et al., 2012). The different accumulation trend of 2AP content in different rice variety could be explained by several factors such as different condition of growth and difference between rice varieties (Yoshihashi et al., 2004; Poonlaphdecha et al., 2012; Mo et al., 2015).

This study showed that, 2AP content from roots of Thai black glutinous was quantified, while previous researches reported that, 2AP content has been obtained only in aerial parts of rice (Buttery et al., 1983; Yoshihashi et al., 1999; 2002). The highest $2 \mathrm{AP}$ content of rice roots were found at seedling stage I, and the lowest $2 \mathrm{AP}$ content of rice roots were found at seedling stage II. The $2 \mathrm{AP}$ accumulation in the root of rice in our study could be explained by the expression level of Badh2 which inhibited 2AP production (Bradbury et al., 2005; 2008). The transcription of Badh2 was expressed less in aroma rice than non-aroma rice. It is significantly expressed in seedling tissues than mature, and also had the least expression level in mature roots than other tissue (Chen et al., 2008; Niu et al., 2008; Hinge et al., 2016). The lower expression level of Badh2 in root parts of aroma rice could be the reason for the accumulation of $2 \mathrm{AP}$ in roots of our experiment. For comparison of $2 \mathrm{AP}$ accumulation between shoot part and root part, the $2 \mathrm{AP}$ content at seedling stage I of root part was 2.2-fold higher than shoot part. Then at seedling stage II, the $2 \mathrm{AP}$ content in root part was 36 -fold lower than shoot part (Table 2 and 3 ). These results indicated that $2 \mathrm{AP}$ content was synthesized in the root part of rice at seedling stage I and then translocated to other parts of rice. The similar result has been reported, in which some aroma compounds of rice is synthesized in some part of rice and then translocate to other parts (Hinge et al., 2016).

The study of gamma irradiation effect have been previously reported on plants and rice such as seed germination, some plant chemical compounds and phytohormone compound (Kumar et al., 2013; Chen et al., 2015; Qi et al., 2015). Here, the 2AP content was investigated when rice was subjected to gamma ray. 2AP accumulation of irradiated rice was altered when compared to non-irradiated rice. The trend of 2AP accumulation in irradiated rice was difficult to explain due to variation of $2 \mathrm{AP}$ content during growth of rice. The $2 \mathrm{AP}$ content in shoots and roots of some gamma dose of irradiated rice was higher than non-irradiated rice. At $20 \mathrm{~Gy}$, the $2 \mathrm{AP}$ content was highest when compared with other gamma doses and also non-irradiated rice. The irradiated rice which was treated with 20 gamma dose could not survive through flowering stage, while the $2 \mathrm{AP}$ content of $20 \mathrm{~Gy}$ plant at panicle initiation stage was the highest (Table 2). This case may support the study of Niu et al. (2008), in which they explained that the high expression level of Badh2 was shown in young and fresh tissue rather than mature tissue. Hinge et al. (2016) has also reported that high expression level of Badh2 show trace amount of $2 \mathrm{AP}$, and low expression level of Badh2 is the cause of high amount of 2AP. In our experiment, Table 1 and 2 show that the growth rate of plant at $20 \mathrm{~Gy}$ plants was significantly decreased but the $2 \mathrm{AP}$ content increased. On the other hand, the growth rate of nonirradiated plants ( $0 \mathrm{~Gy})$ and irradiated plants treated with 150 gamma dose was increased but the 2AP content decrease. Previous reports and our results suggest that mature tissue and damaged tissue may have a higher 2AP level than young and fresh tissues, and also the stress conditions may cause higher 2AP accumulation in rice than normal conditions. 
Our reports showed that, the gamma irradiation caused the reduction in rice grains yield and the 100-grains weight, by which the irradiated rice had lower yield and the 100-grains weight than non-irradiated rice, except for 100-grains weight of irradiated rice treated with 150 gamma dose (Table 4 ). The similar result was observed in the study of El-Degwy (2013). The rice mutant $\left(\mathrm{M}_{2}\right.$ generation after gamma ray) significantly exhibited reduced grains weight, compared to control rice. On the other hand, the 2AP content of irradiated rice grains had higher values than non-irradiated rice grains (Table 4). The accumulation of $2 \mathrm{AP}$ in rice grain was explained by two mechanisms. First, the accumulated 2AP in grains has translocated from other part of rice tissues into the rice grains. Secondly, the accumulated $2 \mathrm{AP}$ in rice grains was synthesized via L-proline metabolism and then the proline content translocated from other part of rice tissues into rice grains (Poonlaphdecha et al., 2012; 2016; Hinge et al., 2016; Mo et al., 2016). The translocation of 2AP content from other part of rice into the rice grains may support the accumulation of $2 \mathrm{AP}$ in irradiated rice grains in this report. The 2AP content of irradiated rice shoots at flowering stage (before harvested stage) was higher than non-irradiated rice shoots (Table 2). Then, 2AP content of rice shoots were migrated into the rice grains at harvest stage, whereas this may explain how the 2AP content of irradiated rice grains is higher than non-irradiated rice grains (Table 4).

\section{Materials and Methods}

\section{Plant material and gamma irradiation}

Seeds samples (Oryza sativa L.) were collected from the rice field in Petchabun province, Thailand. Twenty five grams of rice seeds (approximately $<13 \%$ moisture content) were packed in polyethylene bag and gamma irradiated using ${ }^{137} \mathrm{Cs}$ gamma source at room temperature. The samples were exposed to irradiation doses of 0 (control), 20, 40, 60, 80, $100,150,200$ and $250 \mathrm{~Gy}$ with a dose rate of $3 \mathrm{~Gy} \cdot \mathrm{min}^{-1}$. The gamma irradiation treatments were provided by Gamma Irradiation Service and Nuclear Technology Research Center, Faculty of Science, Kasetsart University, Thailand.

\section{Plant growth conditions}

Rice seeds (100 seeds per irradiation doses) were germinated on germinating paper moistened with distilled water. Rice samples from different doses were harvested randomly at the end of 7 days (seedling stage I) and 14 days (seedling stage II). The harvested rice seedlings were dissected into two separate parts (shoots and roots) and linear growth of shoot system were recorded. Twenty 14-day-old rice seedlings were transferred into the pots containing garden soil and plants were watered once a day $(500 \mathrm{~mL}$ per pot). Plants of different gamma doses were harvested and separated to shoots and roots at the end of 37 days (middle tillering stage), 52 days (panicle initiation stage), 74 days (flowering stage) and 101 days (harvested stage), and linear growth of shoot were recorded. Rice panicles were collected and recorded when rice flowered and seed become mature. All plant samples (approximately 3 gram) were kept at $-20{ }^{\circ} \mathrm{C}$ for analysis of $2 \mathrm{AP}$ content.

\section{Extraction of 2AP from shoots and roots}

Three grams of rice samples were homogenized with a CryoMill (Retsch, Germany) with the liquid nitrogen cooling. The $0.3 \mathrm{~g}$ of homogenized samples were weighed into $2 \mathrm{~mL}$ of plastic tube and then $760 \mu \mathrm{L}$ of ethanol solution containing $10 \mu \mathrm{L}$ of $0.01 \mathrm{mg} \cdot \mathrm{mL}^{-1}$ internal standard TMP were added into the micro centrifuge tubes. The samples were mixed at high speed with a vertex mixer first, then mixed vertically at low speed with a multi Bio RS-24 vertical rotator mixer (BIOSAN, Latvia) at room temperature for 2 hours. After mixing, the samples were centrifuged at $13,000 \mathrm{rpm}$ for 10 minutes and then the supernatants were subjected to Gas Chromatography-Mass Spectrometry (GC-MS).

\section{Preparation of 2AP standard solution}

2AP was purchased from BOC Sciences (New York, USA) with the purity of $95 \%$. The $5 \mathrm{mg} \cdot \mathrm{mL}^{-1}$ of stock solution was prepared by adding $2 \mathrm{~mL}$ of methanol-toluene (1:1) to $10 \mathrm{mg}$ of $2 \mathrm{AP}$, then diluted to $0.01,0.05,0.1,0.5,1.0,2.5 \mathrm{mg} \cdot \mathrm{mL}^{-1}$ with ethanol. The internal standard trimethyl pyridine (TMP) was prepared as $0.01 \mathrm{mg} \cdot \mathrm{mL}^{-1}$ in ethanol. The calibration standard solutions were prepared by adding $10 \mu \mathrm{L}$ of different concentration of $2 \mathrm{AP}$ standard and $10 \mu \mathrm{L}$ of TMP internal standard solution to $750 \mu \mathrm{L}$ of ethanol.

\section{Analysis of $2 A P$ content with GC-MS}

A Bruker Gas Chromatograph 450-GC and TQ mass Spectrometer 320-MS were used for this analysis. A $4 \mu \mathrm{L}$ portion of the extract was injected into a DB-Wax $(60 \mathrm{~m} \times$ $0.25 \mathrm{~mm}$ i.d. $\times 0.25 \mu \mathrm{m}$ film thickness) fused silica capillary column (J\&W Scientific, Folsom, CA). The injector was set at $250{ }^{\circ} \mathrm{C}$, and splitless mode was applied in the first 0.75 min. Helium gas was used as the carrier gas with a constant flow rate of $1.5 \mathrm{~mL} \cdot \mathrm{min}^{-1}$. The following oven temperature program was used and column temperature was isothermally maintained at $40{ }^{\circ} \mathrm{C}$ for $2 \mathrm{~min}$, programmed at a rate of 10 ${ }^{\circ} \mathrm{C}$. $\mathrm{min}^{-1}$ to $100{ }^{\circ} \mathrm{C}$, then at a rate of $5^{\circ} \mathrm{C} \cdot \mathrm{min}^{-1}$ to $150{ }^{\circ} \mathrm{C}$, and then at a rate of $30{ }^{\circ} \mathrm{C} \cdot \mathrm{min}^{-1}$ to $250{ }^{\circ} \mathrm{C}$. The column temperature was then maintained isothermally at $250{ }^{\circ} \mathrm{C}$ for $20 \mathrm{~min}$. The mass spectrometer was used in the electron ionization mode.

The ion source temperature was set at $250{ }^{\circ} \mathrm{C}$, and ionization energy set at $70 \mathrm{eV}$. Multi reaction monitoring (MRM) mode was set up to analyzed 2AP. The precursor ion $\mathrm{m} / z, 111$ and the product ion $\mathrm{m} / \mathrm{z} 83$ were selected for $2 \mathrm{AP}$ with collision energy of $10 \mathrm{v}$, and the precursor ion $\mathrm{m} / \mathrm{z}, 121$ and the product ion $\mathrm{m} / \mathrm{z}, 79$ were selected for TMP with collision energy of 30 v. MS detection dwell time was $100 \mathrm{~ms}$ for each ion. Under these conditions, the retention times of $2 \mathrm{AP}$ and TMP were found to be 13.75 and $14.85 \mathrm{~min}$, respectively. Quantification was performed by measuring the area ratios between ions at $m / z 83$ and 79, corresponding to $2 \mathrm{AP}$ and TMP respectively. The amounts of $2 \mathrm{AP}$ were calculated from its calibration curve.

\section{Statistic analysis}

The data were expressed as mean \pm standard deviation. The experimental design was completely randomized design (CRD) with 6 replicates for rice shoot length and 3 replicates for $2 \mathrm{AP}$ content of shoots and roots of rice. One-way analysis of variance (ANOVA) was carried out using the SPSS version 22.0 software for window (IBM customer no.441840, Phetchabun Rajabhat University), and means were compared using Duncan's multiple range test at 5\% probability. 


\section{Conclusion}

In this work, shoot length, 2AP content and grain weight of irradiated and non-irradiated rice during growth were investigated. The shoot length was increased at low gamma dose except for $20 \mathrm{~Gy}$, while the shoot length at high gamma dose was decreased. The 2AP content of rice shoots of nonirradiated rice was decreased during growth when rice passed through middle tillering stage until panicle initiation stage. Then 2AP content seemed to increase again, when rice passed through flowering stage and harvest stage. In root, the highest 2AP content was obtained from seedling stage I of non-irradiated rice and also from irradiated rice. In shoot and root part, 2AP content of irradiated rice seemed to increase, when rice treated with high gamma dose, higher than nonirradiated rice. The variable amount of $2 \mathrm{AP}$ content was found in irradiated plant either shoot or root parts during growth stage. The results suggest that the trend of rice growth was induced by low gamma dose, while at high gamma dose the rice growth was inhibited. On the other hand, the 2AP content of irradiated rice shoot treated with high gamma dose seem to be higher than irradiated rice shoot treated with low gamma dose. The trend of grain weight of irradiated rice was decreased when compared with grain weight of nonirradiated rice accept for $150 \mathrm{~Gy}$, while the 2AP content of irradiated rice grain seemed to be higher than non-irradiated rice grain. Moreover, the trend of $2 \mathrm{AP}$ content in rice grains was increased when rice treated with high gamma dose. Thus, our results indicated that some gamma doses may be suitable for improvement of $2 \mathrm{AP}$ content and grain-yield quality, such as rice treated with 150 Gy gamma irradiation.

\section{Acknowledgments}

This work was supported by the National Research Council of Thailand (Grant 2558A14503032), the Higher Education Research Promotion and National Research University Project of Thailand, Office of the Higher Education Commission, Rajamangala University of Technology Thanyaburi and Phetchabun Rajabhat University for their support. We are also grateful to Kannika Phasai for assistance providing plant samples.

\section{References}

Akshatha, Chandrashekar KR, Somashekarappa HM, Souframanien J (2016) Effect of gamma irradiation on germination, growth, and biochemical parameters of Terminalia arjuna Roxb. Radiat Prot Environ. 1, 38-44.

Bounphanousay C, Jaisil P, Sanitchon J, Fitzgerald M, Sackville Hamilton NR, Sanitchon J (2008) Chemical and molecular characterization of fragrance in black glutinous rice from Lao PDR. Asian J Plant Sci. 7:1-7.

Bradbury LM, Fitzgerald TL, Henry RJ, Jin Q, Waters DL (2005) The gene for fragrance in rice. Plant Biotechnol J. 3:363-370.

Bradbury LM, Gillies SA, Brushett DJ, Waters DL, Henry RJ (2008) Inactivation of an aminoaldehyde dehydrogenase is responsible for fragrance in rice. Plant Mol Biol. 68:439449.

Buttery RG, Juliano BO, Ling LC (1983) Identification of rice aroma compound 2-acetyl-1-pyrroline in Pandan leaves. Chem Ind. 23:478-479.

Buttery RG, and Ling LC (1982) 2-acetyl-1-pyrroline: An important aroma component of cooked rice. Chem Ind. 12:958-959.
Charbaji T, Nabulsi I (1999) Effect of low doses of gamma irradiation on in vitro growth of grapevine. Plant Cell Tiss Org. 57:129-132.

Chen S, Yang Y, Shi W, Ji Q, He F, Zhang Z, Cheng Z, Liu $\mathrm{X}$, Xu M (2008) Badh2, encoding betaine aldehyde aehydrogenase, inhibits the biosynthesis of 2-acetyl-1pyrroline, a major component in rice fragrance. Plant Cell. 20:1850-1861.

Chen Y, Jiang W, Jiang Z, Chen X, Cao J, Dong W, Dai B (2015) Changes in physicochemical, structural, and sensory properties of irradiated brown japonica rice during storage. J Agric Food Chem. 63:4361-4369.

El-Degwy IS (2013) Mutation induced genetic variability in rice (Oryza sativa L.). Intl J Agric Crop Sci. 5:2789-2794.

Emrani A, Razavi A, Rahimi MF (2013) Assessment of gamma ray irradiation effects on germination and some morphological characters in to corn cultivars. Intl J Agric Crop Sci. 5: 1235-1244.

Gay F, Maraval I, Roque S, Gunata Z, Boulanger R, Audebert A, Mestres C (2010) Effect of salinity on yield and 2-acetyl-1-pyrroline content in the grains of three fragrant rice cultivars Oryza sativa L. in Camargue (France). Field Crops Res. 117:154-160.

Harding SS, Johnson SD, Taylor DR, Dixon CA, Turay MY (2012) Effect of gamma rays on seed germination, seedling height, survival percentage and tiller production in some rice varieties cultivated in Sierra Leone. Am J Exp Agric. 2:247-255.

Hinge V, Patil H, Nadaf A (2016) Comparative characterization of aroma volatiles and related gene expression analysis at vegetative and mature stages in basmati and non-basmati rice (Oryza sativa L.) cultivars. Appl Biochem Biotechnol. 178:619-39.

Huang TC, Teng CS, Chang JL, Chuang HS, Ho CT, Wu ML (2008) Biosynthetic mechanism of 2-acetyl-1-pyrroline and its relationship with Delta1-pyrroline-5-carboxylic acid and methylglyoxal in aromatic rice (Oryza sativa L.) callus. J Agric Food Chem. 56:7399-7404.

Hwang JE, Ahn JW, Kwon SJ, Kim JB, Kim SH, Kang SY, Kim DS (2014) Selection and molecular characterization of a high tocopherol accumulation rice mutant line induced by gamma irradiation. Mol Biol Rep. 41:7671-7681.

Kaneko S, Sakai R, Kumazawa K, Usuki M, Nishimura O (2013) Key aroma compound in roasted in-shell peanuts. Biosci Biotechnol Biochem. 77:1467-1473.

Kara Y, Ergun Z, Vaizogullar EH (2015) The effect of different gamma radiation applied on Tokak-157/37 Barley (Hordeum vulgare) and Karahan-99 Wheat (Triticum aestivum) on M1 Generation. Int J Sec Metabolite. 2:8-12.

Kiefl J, Pollner G, Schieberle P (2013) Sensomics analysis of key hazelnut odorants (Corylus avellana L. 'Tonda Gentile') using comprehensive two-dimensional gas chromatography in combination with time-of-flight mass spectrometry (GC×GC-TOF-MS). J Agric Food Chem. 61:5226-5235.

Kim DS, Lee IS, Jang CS, Kang SY, Song HS, Lee YI, Seo YW (2004) Development of AFLP-derived STS markers for the selection of 5-methyltryptophan-resistant rice mutants. Plant Cell Rep. 23:71-80.

Kim JH, Chung BY, Kim JS, Wi SG (2005) Effects of in Planta gamma-irradiation on growth, photosynthesis, and antioxidative capacity of red pepper (Capsicum annuum L.) Plants. J Plant Biol. 48:47-56.

Kiong ALP, Lai AG, Hussein S, Harun AR (2008) Physiological responses of orthosiphon stamineus plantles to gamma irradiation. Am-Eurasian J Sustain Agric. 2:135149. 
Kovacs E, Keresztes A (2002) Effect of gamma and UV-B/C radiation on plant cells. Micron. 33:199-210.

Kumar PD, Chaturvedi A, Sreedhar M, Aparna M, VenuBabu P, Singhal RK (2013) Gamma radiosensitivity study on rice (Oryza sativa L.). Asian J Plant Sci Res. 3: 54-68.

Kumazawa K, Masuda H (2002) Identification of potent odorants in different green tea varieties using flavor dilution technique. J Agric Food Chem. 50:5660-5663.

Maraval I, Mestres C, Penin K, Ribeyre F, Boulanges R, Guichard E, Gunata Z (2008) Odor-active compounds in cooked rice cultivars from camargue (France) analyzed by GC-O and GC-MS. J Agric Food Chem. 56:5291-5298.

Marcu D, Damian G, Cosma C, Cristea V (2013) Gamma radiation effects on seed germination, growth and pigment content, and ESR study of induced free radicals in maize (Zea mays). J Biol Phys. 39:625-634.

Mo Z, Li W, Pan S, Fitzgerald TL, Xiao F, Tang Y, Wang Y, Duan M, Tian H, Tang X (2015) Shading during the grain filling period increases 2-acetyl-1-pyrroline content in fragrant rice. Rice. 8:9.

Niu X, Tang W, Huang W, Ren G, Wang Q, Luo D, Xiao Y, Yang S, Wang F, Lu BR, Gao F, Lu T, Liu Y (2008) RNAi-directed downregulation of OsBADH2 results in aroma (2-acetyl-1-pyrroline) production in rice (Oryza sativa L.). BMC Plant Biol. 8:100.

Poehlmann S, Schieberle P (2013) Characterization of the aroma aignature of Styrian Pumpkin seed oil (Cucurbita реро subsp. pepo var. Styriaca) by molecular sensory science. J Agric Food Chem. 61:2933-2942.

Poonlaphdecha J, Maraval I, Roques S, Audebert A, Boulanger R, Bry X, Gunata Z (2012) Effect of timing and duration of salt treatment during growth of a fragrant rice variety on yield and 2-acetyl-1-pyrroline, proline, and GABA Levels. J Agric Food Chem. 60:3824-3830.

Poonlaphdecha J, Gantet P, Maraval I, Sauvage FX, Menut C, Morere A, Boulanger R, Wust M, Gunata Z (2016) Biosynthesis of 2-acetyl-1-pyrroline in rice calli cultures: Demonstration of 1-pyrroline as a limiting substrate. Food Chem. 197:965-971.

Prasada KE, Murty DS (1979) A basmati (scented) sorghum from Madhya Pradesh. Curr Sci. 48:824-826.

Preuss SB, Britt AB (2003) A DNA-damage-induced cell cycle checkpoint in Arabidopsis. Genetics. 164:323-334.
Qi W, Zhang L, Feng W, Xu H, Wang L, Jiao Z (2015) ROS and $\mathrm{ABA}$ signaling are involved in the growth stimulation induced by low-dose gamma irradiation in Arabidopsis seedling. Appl Biochem Biotechnol. 175:1490-1506.

Tairu AO, Hofmann T, Schieberle P (2000) Studies on the key odorants formed by roasting of Wild Mango Seeds (Irvingia gabonensis). J Agric Food Chem. 48: 2391-2394.

Warchalewski JR, Pradzynska A, Gralik J, Nawrot J (2002) The effect of gamma and microwave irradiation of wheat grain on development parameters of some stored grain pests. Nahrung. 44:411-414.

Widjaja R, Craske JD, Wootton M (1996) Comparative studies on volatile components of non-fragrant and fragrant rices. J Sci Food Agric. 70:151-161.

Wongpornchai S, Sriseadka T, Choonvisase S (2003) Identification and quantitation of the rice aroma compound, 2-acetyl-1-pyrroline, in bread flowers (Vallaris glabra Ktze). J Agric Food Chem. 51:457-462.

Wu Ml, Chou Kl, Wu CR, Chen Jk, Huang TC (2009) Characterization and the possible formation mechanism of 2-acetyl-1-pyrroline in aromatic vegetable soybean (Glycine max L.). J Food Sci. 74:192-197.

Yajima I, Yanai T, Nakamura M (1978) Volatile flavour components of cooked rice. Agric Biol Chem. 42:12291233.

Yajima I, Yanai T, Nakamura M, Sakakibara H, Hayashi K (1979) Volatile flavour components of cooked Kaorimai scented rice. Agric Biol Chem. 43:2425-2430.

Yoshihashi T, Huong NT, Inatomi H (2002) Precursors of 2acetyl-1-pyrroline, a potent flavor compound of an aromatic rice variety. J Agric Food Chem. 50:2001-2004.

Yoshihashi T, Huong NT, Kabaki N (1999) Quality evaluation of Khao Dawk Mali 105, an aromatic rice variety of northeast Thailand. JIRCAS Working Report. 30:151-160.

Yoshihashi T, Nguyen T, Kabaki N (2004) Area dependency of 2-acetyl-1-pyrroline content in an aromatic rice variety, Khao Dawk Mali 105. Jpn Agric Res Q. 38: 105-109.

Yundaeng C, Somta P, Tangphatsornruang S, Wongpornchai S, Srinives P (2013) Gene discovery and functional marker development for fragrance in sorghum (Sorghum bicolor (L.) Moench). Theor Appl Genet. 126: 2897-2906. 